\title{
EGYMÁS SZEMÉBE NÉZVE
}

Az Egymás szemébe nézve címü kötet az elmúlt ötven év roma politikai törekvéseit mutatja be a roma mozgalmak résztvevői, aktivisták és politikusok szemszögéből. A kötetben bemutatott kutatás tág értelemben vett témája a romák társadalmi integrációja, ám e kérdést egy igen újszerü nézőpontból, személyes élettörténeteken keresztül, a politikai szereplővé válás folyamatainak, a motivációknak, döntési helyzeteknek és választásoknak szempontjából vizsgálja.

Hiánypótló vizsgálatról és kötetről van tehát szó, mivel a témával korábban foglalkozó kutatások nem a romák szempontjait igyekeztek feltárni - hangsúlyozzák a szerzők. Egyúttal egy definíciós félreértés tisztázását is megkísérlik, hiszen a közbeszéd magán a roma politika kifejezésen is sokszor a romákat mint társadalmi és etnikai csoportot érintő olyan elképzeléseket, döntéseket és intézkedéseket ért, amelyeket a - csoporton kívül álló - többségi hatalom képviselői fogalmaznak és hoznak meg. A kötet összeállítói (Kóczé Angéla, Neményi Mária és Szalai Júlia) ezen a látószögön kívántak változtatni, és arra törekedtek, hogy úgy mutassák be az elmúlt fél évszázad roma politikáját, ahogy azt maguk a szereplők élték végig, és ahogyan azt ők belső pozíciójukból értelmezik.

Ennek érdekében a kutatók olyan vizsgálatot végeztek, amelynek során összesen ötvenöt interjút készítettek. Ezekből harmincötöt olyan roma közéleti szereplőkkel, akiknek az élettörténetében a roma politizálás bizonyos szempontból fontos szerepet játszott; további húsz interjú pedig családtagokkal készült, azaz olyan személyekkel, akik valamilyen formában kapcsolódtak, szülei, testvérei, házastársai voltak egy-egy közszereplőnek. A 2012-ben elkezdett és 2016-ban lezárult kutatás módszertani innovációja, hogy az életútinterjúk egy részének felvétele a Roma Parlamentben közönség - roma és nem roma politikai aktivisták, szakértők és családtagok - előtt zajlott.

A kötet elején három tanulmányt olvashatunk. Az első írásban Kóczé Angéla bemutatja, hogy mire vállalkoztak a szerkesztők, és milyen módszertannal dolgoztak. A kutatás alapjául szolgáló anyagot három szinten elemezték, amely során a társadalmi és politikai intézményrendszerből eredő lehetőségek és korlátok makroszintü elemzését, az adott politikai, társadalmi és jogi gyakorlatok szervezeti/mozgalmi megjelenítésének vizsgálatát (mezoszint), valamint az adott gyakorlatok egyes közéleti szerepet vállaló romák személyes és közösségi ambícióira, egyéni vagy közösségi politikai szerepvállalására tett hatásának elemzését (mikroszint) végezték el. Kóczé kiemeli, hogy munkájuk szorosan kapcsolódik ahhoz a nemzetközi tudományos vitához, amelynek egyik legfontosabb szereplője Michael Burawoy, a ,public sociology" egyik élharcosa. Ezen irányzat szerint a szociológiának a köz javát kellene szolgálnia, ezért tartalmilag és módszertanilag is meg kell újulnia, és ennek a 
megújulásnak ,alulról”, a civil társadalom felől kell jönnie. A szerző hangsúlyozza, hogy a tárgyalt kötetben bemutatott vizsgálat maga is egy demokratizációs folyamat, amelynek során a kutatás vezetöi arra törekedtek, hogy olyan helyzeteket teremtsenek, amelyekbe azok is be tudnak kapcsolódni, akik marginális helyzetükböl adódóan eddig nem tudtak részt venni tudományos vizsgálódásokban.

Az interjúk mellett a kutatók nyilvános kerekasztal-beszélgetéseket is szerveztek, amelyek során roma és nem roma társadalomtudósok, közéleti és közpolitikai szereplők vitatták meg a vizsgálat alapvető kérdéseit és dilemmáit. A kötet egyik nagy erénye, hogy ezeknek a kerekasztal-beszélgetéseknek a szerkesztett változatai is bekerültek a könyvbe. Emellett az elmúlt fél évszázad roma politikájának a szerkesztők által legfontosabbnak vélt dokumentumait - például felszólalásokat, beszédeket, javaslatokat, pályázati felhívást, kiállításmeghívót stb. - és a legfontosabb szereplök életrajzait is megtaláljuk a kötetben. A nyilvánosan felvett életútinterjúk és a kerekasztal beszélgetések Roma Polgárjogi Esték címmel a Magyar Tudományos Akadémia Szociológiai Kutatóintézetének a 20. Század Hangja Archívumában elérhetőek az interneten is. Ilyen módon ezek az anyagok a jövőbeni kutatásoknak is elemzési alapul szolgálhatnak, sőt az egyetemi oktatásban is hasznát láthatjuk a szerkesztők azon törekvésének, hogy minél nyitottabbá, ahogy ők írják, demokratikusabbá tegyék kutatásukat.

Másik kutatói törekvésük az volt, hogy minél több roma munkatársat vonjanak be a munkába, így az interjúk egy részét egyetemet végzett roma fiatalok készítették - amivel intergenerációs párbeszédet generálhattak a roma elit fiatal és idős nemzedéke között -, és emellett sikerült elérni roma és nem roma kutatók egyenrangú részvételét a kutató és elemző munka minden fázisában - írja Kóczé Angéla.

Neményi Mária és Szalai Júlia tanulmánya részletesen elemzi a vizsgálat során felvett anyagokat. Az interjúalanyok különböznek abból a szempontból, hogy közéleti szerepüket hol és hogyan - döntően civil szervezetben, mozgalmi formában, állami/önkormányzati intézmény képviseletében, párthoz csatlakozva vagy nemzetközi szervezet munkatársaként - töltik/töltötték-e be, illetve abban is, hogy jellemzően mely időszakhoz kötődik megjelenésük és aktivitásuk. Tehát a vizsgálat alanyai igen változatos életutakat képviselnek, ugyanakkor a kutatók törekedtek arra, hogy egy közös narratívát fejtsenek fel. Ennek érdekében részletesen vizsgálták, hogy a megkérdezettek milyen környezetben szocializálódtak, kik és mik hatottak a pályaválasztásukra és az identitásuk fejlődésére, milyen tágabb értelembe vett társadalmi, politikai és közéleti tényezök, fordulatok, valamint milyen személyes döntések és motivációk voltak hatással későbbi pályájukra. Mindeközben a maguk történetiségébe ágyazva figyelhetjük meg az alanyok roma identitásának pozitívvá válását, illetve annak kiteljesedését. Izgalmas látni, hogy a kezdeti radikális, rendszerkritikával összekapcsolódó mozgalmi indíttatás hogyan halad a professzionalizálódás irányába, és hogyan váltak emblematikus figurákká a roma politika legendás alakjai. 
A kötet harmadik tanulmányában Bogdán Mária a nyilvánosság fokozatosan átalakuló színtereit, a közösségi hálózatokat a roma mozgalmak szemszögéből értelmezi. A szerző szerint az interneten szerveződő közösségi hálózatok azért is figyelemre méltóak, mivel olyan társadalmi csoportok számára kínálnak lehetőséget a megszólalásra és a részvételre, amelyek eddig marginális helyzetükből következően nehezen vagy egyáltalán nem tudtak közvetlenül beleszólni az őket érintő társadalmi folyamatokba. Bogdán az „Ide tartozunk!” - Roma közösségi hálózat képviselőivel készített interjúkat, és ezek mellett más tematikus anyagokat, weboldalakat is elemez.

Talán ebből a rövid áttekintésből is kitünik, hogy milyen széles olvasói réteg számára lehet tanulságos a kötet. Amellett, hogy a közölt interjúk, beszélgetések és dokumentumok mind társadalomkutatók, mind történészek számára további kutatások alapanyagául szolgálhatnak, az elemzések mély és alapos megértésre adnak lehetőséget. De nem csak kutatóknak ajánlható a könyv, hiszen minden, a témában tájékozódni vágyó olvasónak is iránytűként szolgálhat.

Ugyan a roma politika történetének nincs kőbe vésett kánonja - írja Neményi Mária és Szalai Júlia - ezzel a kötettel mégis a szereplök kanonizálása felé tesznek lépéseket. Egyetérthetünk a szerzőkkel abban, hogy az elemzésekben felfejtett narratívákból kiolvasható az elmúlt fél évszázad roma politikájának belülről láttatott és belső története. E történet egyik legnagyobb tanulságát így foglalják össze a szerzők: „Miután a rendszerváltás előtti társadalmi-gazdasági feltételek a cigányság számára az asszimilációt kínálták fel mint a felemelkedés egyedül járható útját, de a cigányság minden beolvadási igyekezete ellenére folytonosan szembeütközött az elutasítással és megkülönböztetéssel, ez az ellentmondásos elvárásrendszer óhatatlanul ráébresztette a romák helyzetén változtatni akarókat az elnyomás rasszista jellegére.” (67.) Végül a szerzők nem festenek optimista képet a jövőről: „E körülmények között ma semmivel sem kevésbé aktuális a szélsőséges választásokat megjelenítő dilemma, mint évtizedekkel ezelött: beolvadás a roma identitás feladásával vagy etnikai elkülönülés a kirekesztettség vállalásával. Ahogy láttuk korábban, mindkét út egyéni lemondásokkal és aligha megspórolható életút-törésekkel társul, és nincs okunk feltételezni, hogy napjainkban - vagy akár a közeli jövőben - mindez máshogy lenne. A roma politika igencsak szűkre szabott terét a két pólus harca zárvánnyá változtatja, $\mathrm{s}$ a legtöbb, ami várható, hogy e helyzet abszurditása legalább kimondható.” (69.) A kötet szerkesztői ezt megtették, most rajtunk, olvasókon a sor, hogy halló és értő fülekre találjon ez a gondolat.

(Kóczé Angéla - Neményi Mária - Szalai Júlia szerkesztők: Egymás szemébe nézve. Az elmúlt fél évszázad roma politikai törekvései. Szociológiai Tanulmányok. Budapest: MTA TK Szociológia Intézet, 2017.)

Kenéz Anikó

PhD-jelölt, Eötvös Loránd Tudományegyetem Szociológia Doktori Iskola Interdiszciplináris Program 